\title{
Historical Costs versus Fair Value Measurement in Financial Accounting ${ }^{\#}$
}

\author{
Dana DVǑ̌́́KOVÁ*
}

\section{Introduction}

Measurement is a core issue of financial accounting and reporting today. International Accounting Standards Board (IASB) and national standard setters in particular countries deal with this issue.

The following main issues of the measurement in financial accounting are discussed at present:

- convergence of approaches to the fair value measurement between the US GAAP and the IFRS;

- using the fair value measurement on initial recognition and further at a balance sheet day (there is an assumption to eliminate historical costs measurement completely);

- possible changes in measurement approaches in the period of crisis.

There are two measurement concepts standing against each other:

1. Historical costs (based on entity specific measurement and impairment recognition)

2. Measurement which reflects present economic conditions at the day of measurement:

- the fair value measurement; and

- an entity specific measurement:

\# This paper was prepared in the framework of research plan Development of Accounting and Financial Theory and its Application in Practice from Interdisciplinary Point of View (registered number MSM 6138439903).

* Doc. Ing. Dana Dvořáková, Ph.D. - associate professor; Department of Financial Accounting and Auditing, Faculty of Finance and Accounting, University of Economics, Prague, W. Churchill Sq. 4, Prague 3, 130 67, Czech Republic; <ddvorak@vse.cz>. 
- current cost - reproduction cost and replacement cost,

- net realizable value,

- value in use,

- deprival value.

In financial accounting there are two important moments when assets and liabilities need to be measured:

- on initial recognition; and

- at a balance sheet day.

In these points an entity specific measurement or a fair value measurement can be used.

\section{Historical costs}

Historical costs are based on the measurement of assets and liabilities at purchase price (costs) that were incurred at the moment of the purchase. These costs decrease only if an asset is impaired. An asset is impaired when its carrying amount exceeds its recoverable amount (in accordance with IAS 36). Assets impairment is based on an entity specific measurement.

\section{Measurement reflecting present economic conditions at the day of measurement}

Such measurement is based on periodical revaluating of assets (and in some cases also liabilities) at least at a balance sheet day.

The fair value measurement is based on market prices fulfilling the following definition: "Fair value - the amount for which an asset could be exchanged, or a liability settled, between knowledgeable, willing parties in an arm's length transaction." This requires that the assumptions as to how the asset can be used are those adopted by the market, rather than the "entity specific" beliefs of the current owner.

An entity-specific measurement objective looks to the expectations of the reporting entity which may differ significantly from those implicit in a market price. Any measure of an asset or liability that differs from its market value must be based, explicitly or implicitly, on entity-specific expectations that differ from those of the market. 


\section{Measurement in IFRS - nowadays}

The International Financial Reporting Standards (IASB, 2008) lead in an increased extent to use the fair value measurement.

The arguments for the departure from the historical costs base at balance sheet date are as follows:

\section{1) Low information potential of historical cost}

The first argument can be found especially in the case of investments and financial instruments where historical costs have low information capacity which has been criticized mostly by external users of accounting information.

\section{2) Physical capital maintenance}

The second argument against the application of the historical costs base is a hidden aspect of physical capital maintenance erosion. The recognition of expenses that are determined by the inflation undervalued historical costs of consumed assets brings higher profit and its complete distribution to owners can lead to a disability of an enterprise to finance the full reproduction of inputs. There is a clear requirement not only from external users of accounting information but also from the management of an enterprise to depart from historical costs with the goal to recognize the profit at the moment when the physical productive capacity is maintained. The subject of distribution can only be the profit recognized as a result of revenues matched with the expenses measured at current market values that cannot cause physical capital maintenance erosion. But in this case, the enterprise should rather use replacement costs instead of fair values that cannot reflect the conditions in which the enterprise works.

\section{3) Objectivity and comparability of measurement}

The third argument for the fair value measurement is the objectivity and comparability of such fair value measurement that is not based on individual conditions reached at the initial recognition of assets or liabilities.

The consequences of the above mentioned factors were introduced into the IFRS as a required measurement which reflects present economic 
conditions at the day of measurement - especially at a balance sheet day. The IASB prefers the fair value measurement to the entity specific measurement in the IFRS.

Many IFRS are based on the fair value measurement concept.

The fair value is either an equal alternative to the historical costs (e.g. IAS 16 - Property, plant and equipment, IAS 38 - Intangible assets), or it is a preferable or demanded measurement base (e.g. IAS 40 - Investment property, IAS 32 and IAS 39 - Financial instruments, IAS 41 Agriculture).

But most of these standards use the fair value measurement method only at a balance sheet day. On initial recognition assets and liabilities are measured usually at costs.

Only IAS 41 - Agriculture and IAS 39 - Financial instruments require the fair value measurement on initial recognition. An IAS 39 demands the fair value measurement of financial instruments at initial recognition. If a purchase price of a financial asset differs from the fair value, a gains or losses caused by this transaction are recognized.

The fair value measurement on initial recognition brings a significant change into accounting. IAS 41 - Agriculture requires the application of the fair value in measuring biological assets from the point of initial recognition and at each balance sheet date. The same demand is required for the agricultural products measurement at the point of their harvest. The historical costs base is completely diminished. This approach seems to be an indicator of future progress within the IFRS.

\section{Possible future - a target formulated before financial crisis}

The IASB published the discussion paper "Measurement Bases for Financial Accounting - Measurement on Initial Recognition" (IASB paper) in November 2005. The IASB paper proposes that all assets and liabilities should be measured at their fair value on initial recognition when the fair value can be estimated with an acceptable reliability (CASB, 2005). This approach brings a significant change into accounting. 
What are the reasons for a departure from the cost measurement on initial recognition?

Two most important criteria for the selection of appropriate measurement base are the following:

- reliability, and

- relevance.

\section{The reliability of accounting measurements}

According to the IASB paper the reliability of accounting measurements is based on the following three attributes: representational credibility, neutrality and verifiability. I assume that it is the verifiability that can cause practical problems.

\section{The relevance of measurement base}

The IASB paper compares the market and the entity-specific measurement objectives. A market measurement reflects the price in an open and active competitive market, it reflects market expectations. On the contrary an entity-specific measurement is based on the expectations and preferences of the management of an enterprise. The IASB paper proposes that a market value based measurement objective has important qualities that make it more relevant than entity-specific measurement objectives on initial recognition. A measurement which reflects market expectations and conditions is more relevant for accounting information users than a measurement based on the expectations and preferences of the management of an entity. I suppose that this conclusion is in many cases debatable, especially as far as non financial assets. The application of a market value based measurement may result in the use of more models based on subjective management decisions because the market price of most non financial assets and liabilities cannot be detected. In many cases an entity-specific measurement provides greater predictive information than market measurements, that do not reflect specific managerial intentions and therefore the entity-specific measurement can be more relevant for the users of accounting information.

The IASB paper also demonstrates that all the other measurement bases different than fair value directly or indirectly incorporate entity- 
specific measurements. This is the main reason for applying the fair value in measuring assets and liabilities on initial recognition.

The fair value of the consideration given or received (costs) for an item will often represent the fair value of the item at the date of initial recognition. However, there are many cases when the fair value and the historical cost may differ significantly precisely at the moment on initial recognition.

The IASB paper is only the first part of the planned IASB project aimed at measurement. The second part of this project - measurement on a balance sheet date - could probably continue on the same base. The measurement on a balance sheet date will most probably be based on the fair value. Such measurement approach brings a lot of risks especially in the case of a non financial assets measurement. The application of the fair value measurement on initial recognition in IAS 41 - Agriculture, as introduced above, is a precedent for other non financial assets measurements. Some problems concerning an application of the fair value measurement of biological assets and agricultural production can be relevant, after certain generalization, for other non financial assets, for which the requirement of the fair value measurement on initial recognition is completely new.

To begin with it is necessary to accomplish an analysis of IAS 41 measurement approach and to compare them with those proposed in the IASB paper. The approach to measurement in IAS 41 differs from the approach to IASB paper in two points:

- in the setting of measurement hierarchy, and

- in the approach to transaction costs.

\section{Measurement hierarchy}

The basis for an asset's fair value recognition is quoted price in an active market with biological assets or agricultural produce, but only on condition that the market with particular assets exits. If an enterprise has access to different active markets, it will use the price existing in the market that is expected to be used. This base for the measurement included in IAS 41 is also accepted in the IASB paper. 
If an active market does not exist, an enterprise uses the following possibilities for the market price or market value determination, if available:

- The most recent market transaction price on condition that there has not been a significant change in economic circumstances between the date of that transaction and the balance sheet date,

- Market prices of similar assets with an adjustment reflecting the differences between the measured asset and these assets, and

- Sector benchmarks such as the value of an orchard expressed in amounts of fruit (e.g. per export tray, bushel) or hectare, and the value of cattle expressed per kilogram of meat, etc.

In some cases, if the market-determined price or value may not be available for a biological asset in its present condition, an enterprise uses the present value of expected net cash flow from the asset discounted at a current market-determined pre-tax rate in determining its fair value.

The IAS 41 doesn't determine the hierarchy which should be respected when using alternative methods of the market price or market value determination. On the contrary the IASB paper determines such hierarchy. This hierarchy derived from a maximal elimination of entityspecific measurements.

The IASB paper proposes the following measurement hierarchy on initial recognition:

1. An entity should use an observable market price of such assets or liabilities that are identical or similar to the item to be measured, but with an appropriate adjustment to any differences between the market traded assets or liabilities and the asset or liability to be measured, and with an appropriate adjustment to time differences arising from the time difference between a moment of trading and a measurement moment.

2. If the observable market price described in level one cannot be assessed, a model or technique for estimating the market price of an item to be measured on initial recognition is accepted. All significant inputs into this model have to reflect observable relevant market preconditions. 
3. If the measurement methods in levels one and two cannot be used, an asset should be measured on initial recognition at its current cost provided that this amount can be reliably estimated and can be reasonably expected to be recoverable.

4. If the conditions of levels 1, 2 or 3 cannot be met, an asset or liability should be measured on initial recognition on the basis of an accepted model or technique. A measurement model should use reliably estimated entity-specific data that are not significantly inconsistent with observable market information to the extent in which reliable market-based data are unavailable.

\section{Transaction costs and anticipated cost of sales}

The standard IAS 41 requires the measurement of biological assets at their fair value less estimated point-of-sale costs. The point-of-sale costs include commissions to brokers, dealers, levies by regulatory agencies and commodity exchanges, and transfer taxes and duties. The point-ofsale costs exclude transport and other costs necessary to get assets to a market. In compliance with the requirements in IAS 41, the costs necessary to get assets to a market (transport costs) are excluded from the fair value at the moment of its determination. The fair value is a market value less transport costs and other costs necessary to get assets to a market.

This method mixes the market and the entity-specific measurement. The fair value reflexes market conditions while the anticipated transaction costs (point-of-sale costs and costs necessary to get assets on market e.g. transport costs) reflexes future conditions of sale. This measurement is not fully in accordance with the IASB paper which excludes whichever intersection of an entity-specific measurement into an assessment of the fair value and does not permit that future costs necessary to get assets to a market decrease fair value.

When I compared IAS 41 approach and the approach in the IASB paper I came to an assumption that the fair value measurement problems, when applying IAS 41, occur also in case of other non financial assets.

Some arguments against the fair value measurement concept in the case of non financial assets as it is presented in the IASB paper are as follows: 
1. When an active market does not exist a fair value often has lower degree of evidence and reliability. The estimation methods of the fair value on initial recognition (or at a balance sheet date) are based on subjectively estimated entity-specific data. In that case it is better to use historical costs. To determine a limit point at which the fair value cannot be reliably assessed is also problematic and subjective.

2. The gains achieved by the fair value measurement (when the fair value is higher than costs) should not be included in net profit or loss mainly in cases when the fair value is not available for an enterprise in the case of future sales of assets. Moreover, the fixed assets are not available for sale at all.

\section{Partial conclusion}

I suppose that the fair value measurement can bring a lot of relevant information for accounting information users but it brings higher risks when the gains of the fair value measurement are included in net profit or loss of an enterprise, especially in case fair value measurement of non financial assets. From this point of view it would be better to present the fair value measurement information as alternative information, e.g. in a format of alternative income statement and balance sheet. Such form of presentation can be useful for accounting information users and does not bring risk of the physical capital maintenance erosion.

\section{Can the current financial crisis change the approach to measurement in financial accounting?}

The financial crisis can significantly change the approach to measurement in financial accounting. The clearly drafted way to the extended use of the fair value measurement in financial accounting (e.g. in IASB paper mentioned above) can be abandoned or suspended. The issue in the time of financial crisis is using fair value for financial instruments. The reason for possible changes could be the disintegration of financial markets and the unavailability of the fair value of assets (non-financial and also financial). A tendency to suspend the fair value measurement and to use the entity specific measurement instead can be observed. This movement is obvious from the published opinions of experts and relevant organizations and institutions as follows: 
The Securities and Exchange Commission (SEC) and the Financial Accounting Standards Board (FASB) issued "clarifications" regarding the rule, known as mark-to-market. The new directive allows companies to value their assets according to their estimated future cash flow, rather than current market prices (Dougherty, 2008). SEC had finally decided to permit alternative accounting methods to mark-to-market accounting for securities where no active market exists (SEC, 2008). "There are few buyers for many of the assets on the books of financial institutions, especially mortgage-backed securities. That makes them difficult to value. The price uncertainty has driven their market value down as much as 80 percent, threatening the solvency of many banks."

At present this issue seems to be not only a question for financial and accounting experts, but also for politicians. Many economists, business leaders and politicians are urging the modification or suspension of fair value accounting for lenders holding huge amounts of mortgage-backed securities that have no market. They said: "The concept of fair value accounting is correct and useful, but the application during periods of crisis is problematic." Some experts assume that the fair value measurement deepens the financial crisis.

The IASB and the US Financial Accounting Standards Board (FASB) have a long-standing commitment to work together in an internationally coordinated manner on improving financial reporting standards. As part of that commitment, accounting issues emerging from the global crisis will be considered by both boards. The boards established an advisory group comprised of senior leaders with broad international experience with financial markets to assist in that important process (Financial Crisis Advisory Group - FCAG) (IASB, 2009). The IASB and US FASB jointly held public round tables to identify any accounting issues that might require the urgent and immediate attention of the boards. It seems that IASB and US FASB want keep the fair value for financial instruments.

I think that it is necessary to ask nowadays:

- Is it right to use the fair value measurement of assets in periods of an economic boom and distribute uncertain gains from revaluation of assets to owners and managers of firms, and abandon such measurement in the time of crisis when the fair value of assets falls down? 
- Is it correct to base financial accounting only on the fair value measurement in the period of an economic boom without taking into account the uncertainty of market prices and their future movement?

Such questions and doubts are not new, but they are topical at present and should be heard.

\section{Conclusions}

There is not one easy way of measurement in financial accounting. Measurement which reflects present economic conditions at the day of measurement is for accounting information users very useful but it is necessary to prevent the distribution of unrealized gains from revaluation to owners. We should use both measurement approaches (fair value and entity specific value) in accounting to provide correct information to accounting information users. Entity specific measurement for nonfinancial assets may be in some cases better than fair value measurement. Fair value is more appropriate for financial instruments.

\section{References}

[1] CASB (2005): Measurement Bases for Financial Accounting Measurement on Initial Recognition, discussion paper prepared by staff of the Canadian Accounting Standards Board. Toronto, Canadian Accounting Standards Board, 2005.

[2] Dougherty, J. (2008): Can an Accounting Fix End the Financial Crisis? [on-line], Washington Independent, $2^{\text {nd }}$ October, 2008, [cit. $10^{\text {th }}$ October, 2009], <http://washingtonindependent.com/9994/mark-to-market>.

[3] IASB (2008): International Financial Reporting Standards. London, International Accounting Standards Board, 2008.

[4] IASB (2009): IASB Response to the Financial Crisis. [on-line], London, International Accounting Standards Board, c2009, [cit. $10^{\text {th }}$ October, 2009], $<$ http://www.iasb.org/Financial+crisis/Response+to+the+credit+crisis. htm>. 
[5] SEC (2008): Report and Recommendations Pursuant to Section 133 of the Emergency Economic Stabilization Act of 2008: Study on MarkTo-Market Accounting. [on-line], Washington, D.C., United States Securities and Exchange Commission, c2008, [cit. 10 ${ }^{\text {th }}$ October, 2009], <http://www.sec.gov/news/studies/2008/marktomarket123008.pdf>. 


\title{
Historical Costs versus Fair Value Measurement in Financial Accounting
}

\author{
Dana DVOŘÁKOVÁ
}

\begin{abstract}
There are two important points in which in which we need assets and liabilities measured in financial accounting: on initial recognition and at a balance sheet day. Many International Financial Reporting Standards (IFRS) used the fair value measurement concept. But most of these standards use the fair value measurement method only at a balance sheet day. On initial recognition assets and liabilities are measured usually at costs. The IASB presented the discussion paper "Measurement Bases for Financial Accounting - Measurement on Initial Recognition (2005)" which proposed fair value measurement on initial recognition for all assets and liabilities. This article is aimed on assessment of risks arising from extending fair value measurement using and on issue of fair value measurement in time of financial crisis.
\end{abstract}

Key words: Measurement; Accounting; Fair value.

JEL classification: M41. 